\author{
๑๐. М. Павловська, К. М. Павловська
}

Одесъкий нащіональний медичний університет

\title{
ПОРІВНЯЛЬНИЙ АНАЛІЗ ПЕРЕДЧАСНИХ ПОЛОГІВ У ЖІНОК ІЗ НОРМАЛЬНОЮ ТА НАДМІРНОЮ МАСОЮ ТІЛА
}

ПОРІВНЯЛЬНИЙ АНАЛІЗ ПЕРЕДЧАСНИХ ПОЛОГІВ У ЖІНОК ІЗ НОРМАЛЬНОЮ ТА НАДМІРНОЮ МАСОЮ ТІЛА. Передчасні пологи протягом тривалого часу залишаються невирішеною проблемою сучасного акушерства. Було проведено ретроспективне дослідження 120 випадків передчасних пологів у жінок із нормальною та надмірною вагою. Пологи при терміні 22-27 тижнів відбулись у 5 \% жінок, при терміні 28-33 тижні - 35\%, при терміні 34-37 тижнів - 60 \%. Передчасні пологи у 45,8 \% випадків були проведені через природні пологові шляхи, у 54,2 \% - шляхом операції кесаревого розтину. Основними чинниками мимовільних пологів до терміну були передчасне вилиття навколоплідних вод (69,1 \%) та істмікоцервікальна недостатність (25,5 \%). Переважним показанням до оперативного пологорозродження у вагітних із надмірною вагою стали тяжкі форми прееклампсії (ВР 8,35; 95 \% ДІ 1,28-54,45).

СРАВНИТЕЛЬНЫЙ АНАЛИЗ ПРЕЖДЕВРЕМЕННЫХ РОДОВ У ЖЕНЩИН С НОРМАЛЬНОЙ И ИЗБЫТОЧНОЙ МАССОЙ ТЕЛА. Преждевременные роды на протяжении длительного времени остаются неразрешенной проблемой современного акушерства. Было проведено ретроспективное исследование 120 случаев преждевременных родов у женщин с нормальной и избыточной массой тела. Роды в сроке 22-27 недель произошли у $5 \%$ пациенток, в сроке $28-33$ недели - $35 \%$, в сроке 34-37 недель - 60 \%. Преждевременные роды в 45,8 \% случаев были проведены через естественные родовые пути, в $54,2 \%$ - путем операции кесарева сечения. Основными причинами самопроизвольных родов до срока были преждевременное излитие околоплодных вод $(69,1 \%)$ и истмико-цервикальная недостаточность $(25,5$ \%). Преимущественным показанием к оперативному родоразрешению у беременных с избыточной массой тела стали тяжелые фрормы преэклампсии (OP 8,35; $95 \%$ ДИ 1,28-54,45).

COMPARATIVE ANALYSIS OF PRETERM DELIVERIES IN WOMEN WITH NORMAL BODY MASS AND OVERWEIGHT. Preterm deliveries remain unresolved problem of modern obstetrics for a long time. There was conducted a retrospective study of 120 cases of premature deliveries in women with normal body mass and overweight. Births in the period of 22-27 weeks occurred in $5 \%$ of women, in the period of $28-33$ weeks $-35 \%$, in the period of $34-37$ weeks $-60 \%$. Premature deliveries were conducted through the natural birth canal in $45.8 \%$, and by the Cesarean section in $54.2 \%$. The main factors of spontaneous delivery before the term were premature discharge of the amniotic fluids (69.1\%) and cervical incompetence (25.5\%). It was severe form of preeclampsia that became the indication for premature abortion by the Caesarean section in pregnant women with overweight (RR 8.35; $95 \%$ Cl 1.28-54.45).

Ключові слова: передчасні пологи, ожиріння.

Ключевые слова: преждевременные роды, ожирение.

Key words: premature delivery, obesity.

ВСтУп. Передчасні пологи протягом тривалого часу залишаються комплексною медико-соціальною проблемою як в економічно розвинутих країнах, так і в державах, що розвиваються у зв'язку з високим рівнем тяжкої соматичної захворюваності у недоношених новонароджених та перинатальних втрат [1]. В Україні до 7,5 \% пологів відбуваються до терміну. Значущими чинниками пологів до терміну $є$ істміко-цервікальна недостатність (ІЦН), інфекції, передчасний розрив плідних оболонок (ПРПО), диссункція плаценти, вроджена патологія матки та інші [2]. Проте накопичений клінічний досвід та детальний аналіз передчасних пологів свідчать, що саме соматична патологія матері $€$ провідним фрактором ризику даного ускладнення.

На сьогодні провідні дослідницькі медичні організації світу єдині у своїх невтішних висновках та прогнозах людство перебуває на порозі епідемії ожиріння серед населення. Згідно з аналітичними розрахунками, за умови збереження існуючих темпів розповсюдження патології у 2025 році очікується двократне збільшення хворих. За повідомленнями, на сьогодні у США до 24,7 \% вагітних жінок страждає від ожиріння, у Бразилії - 20,1 \%, Австралії 8,9\%, Китаї-8,0 \%, Індії-6,7\%, середньоевропейський показник складає 12,1 \%, найменший в Японії - 2 \% [3]. В Україні у $15 \%$ вагітних виявляють порушення ліпідного обміну різного ступеня виразності. За даними статистики, саме ожиріння після артеріальної гіпертензії та анемії посідає третє місце в структурі соматичної патології, що сприяє передчасному перериванню вагітності [4]. Отже, тільки подальше кропітке вивчення окресленої проблематики дозволить фрахівцям чітко сорормулювати нові та доповнити існуючі позиції щодо прегравідарної підготовки й тактики ведення вагітних жінок із порушеннями ліпідного обміну.

Мета дослідження - визначення особливостей передчасних пологів у жінок із нормальною та надмірною вагою.

МАТЕРІАЛИ ТА МЕТОДИ. На базі пологового бУДинкУ м. Одеси було проведено ретроспективне дослідження 120 випадків передчасних пологів. Пацієнтки були розділені на дві групи: I група - 60 жінок із нормальною вагою, II група - 60 жінок із надмірною масою тіла. Усім вагітним 
проводилось клініко-лабораторно-інструментальне обстеження та була розроблена тактика ведення передчасних пологів згідно з існуючими клінічними протоколами (наказ МО3 України № 417, № 620, № 624). Індекс маси тіла визначали 3 урахуванням середньостатистичного збільшення маси тіла під час вагітності за фрормулою: IMT= наявна вага - прибавка ваги під час вагітності/зріст, $\mathrm{M}^{2}$. Розподіл пацієнток здійснювався на підставі значення IMT: 18,5-25 кг/M² - нормотрофріки, більше $25 \mathrm{kr} / \mathrm{M}^{2}$ - гіпертросріки.

РЕЗУЛЬТАТИ ДОСЛІДЖЕННЯ ТА ЇХ ОБГОВОРЕННЯ. На підставі проведеного аналізу 120 історій вагітностей та пологів було виявлено, що пологи при терміні 22-27 тижнів відбулись у 6 (5\%) жінок, при терміні 28-33 тижні - 42 (35\%), при терміні 34-37 тижнів - 72 (60\%). У переважної більшості пацієнток із нормальною вагою (81,7 \%) передчасні пологи були проведені через природні пологові шляхи (відносний ризик (ВР) 0,12; $95 \%$ довірчий інтервал (ДІ) 0,06-0,26), у вагітних з надмірною масою тіла, навпаки, шляхом кесаревого розтину (ВР 4,91; $95 \%$ ДІ 2,86-8,43).

У І групі занадто ранні передчасні пологи зафіксовані у 6 жінок (10\%), при терміні 28-33 тижні - 19 (31,7\%), при терміні 34-37 тижнів - 35 (58,3 \%). У групі порівняння переважна більшість передчасних пологів відбулась при терміні 34-37 тижнів - 37 (61,7 \%), при терміні 28-33 тижні - 23 (38,3 \%), отже, у вагітних із надмірною масою тіла в нашому дослідженні не було зареєстровано занадто ранніх передчасних пологів.

У жінок із нормальними ваговими показниками всі пологи при терміні 22-27 тижнів були проведені через природні пологові шляхи. Основними чинниками передчасного переривання вагітності були прогресуюча ІЦН $(66,7 \%)$ та ПРПО (33,3\%). При терміні гестації 28-33 тижні переважна більшість передчасних пологів (84,2 \%) також відбулась через природні пологові шляхи. Проте ведучим фрактором стало вже ПРПО (62,5 \%), ІЦН - $25 \%$ випадків, перерозтягнення матки багатоплідною вагітністю - 12,5 \%. У 3 (15,8 \%) вагітних було проведено оперативне пологорозродження шляхом операції кесаревого розтину у зв'язку з дистресом плода $(66,7 \%)$ та діагностованою набряковою фрормою гемолітичної хвороби плода (33,3 \%). При терміні 34-37 тижнів у 27 (77,1 \%) жінок із нормальною вагою пологи відбувались через природні пологові шляхи. ПРПО, як причина початку пологів до терміну, була засріксована у 74,1 \% випадків, ІЦН - 22,2 \%, перерозтягнення матки багатоплідною вагітністю-3,7\%. Кесарів розтин був проведений у 8 (22,9 \%) вагітних. Найбільш частими показаннями до оперативного пологорозродження були кровотеча внаслідок передчасного відшарування нормально або передлеглої плаценти (37,5 \%) та дистрес плода (25 \%). Також показаннями до кесаревого розтину в дослідженні виступили прогресування прееклампсії (12,5\%), неправильне положення плода/плодів (12,5\%), набрякова фрорма гемолітичної хвороби плода (12,5\%).

Слід зазначити, що у вагітних II групи передчасні пологи при терміні 28-33 тижні відбулись лише шляхом операції кесаревого розтину. Показаннями до оперативного пологорозрождення стали прогресування пізнього гестозу (82,6 \%), дистрес плода (17,4 \%). Пологи при терміні гестації 34-37 тижнів у пацієнток окресленої групи також відбувались переважно оперативно (83,8 \%). Так, прогресування тяжкої прееклампсії спостерігалось у 22 (71 \%) вагітних, кровотечі внаслідок передчасного відшарування нормально розташованої або передлеглої плаценти та дистрес плода були діагностовані у 5 $(16,1 \%)$ та 4 (12,9\%) жінок відповідно. Таким чином, у дослідженні основними показаннями до оперативного пологорозродження у вагітних із надмірною вагою стали тяжкі форми прееклампсії (ВР 8,35; 95 \% ДІ 1,28-54,45), акушерські кровотечі (ВР 0,34; $95 \%$ ДІ 0,10-1,22), дистрес плода (ВР 0,41; 95 \% ДІ 0,15-1,12).

ВисновкИ. За результатами багатовибіркового дослідження, пологи у терміні гестації 34-37 тижнів становлять більшість випадків (60\%), занадто ранні передчасні пологи - меншість (5\%).

У переважної більшості пацієнток із нормальною вагою (81,7 \%) передчасні пологи були проведені через природні пологові шляхи (ВР 0,12; 95 \% ДІ 0,06-0,26), у вагітних із надмірною масою тіла, навпаки, шляхом кесаревого розтину (ВР 4,91; 95 \% ДІ 2,86-8,43).

Основними чинниками мимовільних пологів до терміну в жінок з нормальною масою тіла були передчасне вилиття навколоплідних вод (65,3 \%) та істміко-цервікальна недостатність (28,6 \%). Переважним показанням до оперативного пологорозродження у вагітних із надмірною вагою стали тяжкі форми прееклампсії (ВР 8,35; 95 \% ДІ 1,28-54,45).

Проведення прегравідарної підготовки та профілактичних заходів із попередження прееклампсії у вагітних із надмірною вагою з ранніх термінів гестації (12 тижнів) може стати вагомим фактором зниження частоти передчасного переривання вагітності за медичними показаннями з боку матері та зменшення перинатальних ризиків.

ПЕРСПЕКТИВИ ПОДАЛЬШИХ ДОСЛІДЖЕНЬ. ПОдальші дослідження будуть зосередженні на вивченні особливостей перебігу передчасних пологів у вагітних із метаболічним синдромом із фрормуванням стратегії прегравідарної підготовки у цієї категорії жінок.

3. Романцова Т. И. Эпидемия ожирения: очевидные и вероятные причины / Т. И. Романцова // Ожирение и метаболизм. - 2011. - № 1. - С. 5-18.

4. Роль избыточной массы тела и ожирения в развитии осложнений беременности и родов / И. О. Макаров, Е. И. Боровкова, О. В. Рыкунова [и др.] // Российский вестник акушера-гинеколога. - 2011. - № 3. - С. 21-26. при недоношеній вагітності / В.В.Сімрок, В. Ф. Олеш Неонатологія, хірургія та перинатальна медицина. - 2014 - T. IV, № 4 (14). - C. 79-86. 